\title{
CAG REPEAT NUMBER IN ANDROGEN RECEPTOR GENE AND MALE INFERTILITY
}

\author{
Plaseski $\mathrm{T}^{1,2}$, Noveski $\mathrm{P}^{1}$, Dimitrovski $\mathrm{C}^{2}$, Kocevska B ${ }^{2}$, Efremov GD ${ }^{1}$, \\ Plaseska-Karanfilska $\mathrm{D}^{1, *}$
}

\begin{abstract}
*Corresponding Author: Dr. Dijana Plaseska-Karanfilska, Macedonian Academy of Sciences and Arts, Research Center for Genetic Engineering and Biotechnology, Av. Krste Misirkov 2, POB 428, 1000 Skopje, R. Macedonia; Tel: +389 23235410 Fax: +389 23115 434; E-mail: dijana@, manu.edu.mk
\end{abstract}

\begin{abstract}
Androgens are essential for male sexual development and for fertility. They exert their action through the androgen receptor (AR), a ligandactivated transcription factor. The 5' end of exon 1 of the AR gene includes a polymorphic CAG triplet repeat that varies in number between 10 to 36 in the normal population. There is controversy over an association between high CAG repeat numbers in the AR gene and male infertility. We have evaluated the possible effect of long CAG repeats in the AR on infertility in men from the Republic of Macedonia (R. Macedonia). A group of 222 infertile/subfertile males with different sperm counts and a control group of 152 proven fathers were studied. The CAG repeat number was determined by fluorescent polymerase chain reaction (PCR) amplification of exon 1 of the AR gene analyzed by capillary electrophoresis. Mean CAG length did not differ significantly between males with azoospermia $(22.0 \pm 3.1)$, mild oligozoospermia $(22.4 \pm 2.6)$, severe oligozoospermia $(23.0 \pm 4.2)$, normozoospermia $(21.8 \pm 2.4)$, or known causes of infertility $(22.1 \pm 2.9)$ and fertile controls $(22.3 \pm$ 2.9). However, we found a significantly higher percentage of CAG repeats $>26(p=0.022),>27$

\footnotetext{
${ }^{1}$ Macedonian Academy of Sciences and Arts, Research Center for Genetic Engineering and Biotechnology,

${ }^{2}$ Faculty of Medicine, Clinic of Endocrinology and Metabolic Disorders, Skopje, R. Macedonia
} Skopje, R. Macedonia
\end{abstract}

$(p=0.018)$ and $>28(p=0.009)$ in males with mild oligozoospermia. These results indicate a possible association between CAG repeat length and mild oligozoospermia. Further studies on a larger number of patients with mild oligozoospermia are warranted to confirm this association.

Key words: Androgen receptor (AR); $\mathrm{CAG}$ repeats; Male infertility; Oligozoospermia

\section{INTRODUCTION}

Infertility occurs in $10-15 \%$ of couples, male factor infertility representing about $50 \%$ of the cases [1]. It is now evident that a significant proportion of male infertility is associated with a variety of genetic abnormalities. Genetic defects associated with male infertility include chromosomal aberrations, $\mathrm{Y}$ chromosome microdeletions involving one or more azoospermia factor (AZF) regions, mutations in the cystic fibrosis transmembrane conductance regulator (CFTR) gene, and mutations in the androgen receptor (AR) gene.

Androgens are essential for male sexual development and for fertility. They act through the $\mathrm{AR}$, which is a transcriptional factor that contains functional domains for DNA binding, ligand binding and transcriptional regulation. The 5 ' end of exon 1 of the AR gene includes a polymorphic CAG triplet repeat that codes for a polyglutamine tract. The number of CAG repeats in the normal population varies between 10 and 36. Expansion of the polyglutamine tract to $>38$ repeats in males leads to Kennedy disease [spinal bulbar muscular atrophy 
(SBMA)] [2]. In addition to neurological symptoms, SBMA patients show signs of hypogonadism, such as gynecomastia, impotence, testicular atrophy and reduced fertility.

In vitro studies have demonstrated a negative correlation between $\mathrm{CAG}$ repeat size and AR function [3]. Short AR CAG repeat tracts have been associated with prostate cancer [4] and polycystic ovary syndrome [5], while long CAG repeat tracts have been associated with moderate-to-severe undermasculinization [6], breast cancer [7] and male subfertility [8]. The possible association of a long CAG repeat with male infertility in Asian populations was suggested because of a four-fold increase in the risk of impaired spermatogenesis in males who had $>28$ CAG repeats [8]. Since then, the association of the long CAG repeat number in the AR gene and male infertility has been controversial. This study aims to evaluate the possible effect of long CAG repeat tracts in the AR on infertility among Macedonian men.

\section{MATERIALS AND METHODS}

Materials. A total of 222 patients (representing $231 \mathrm{X}$ chromosomes) attending the Andrological Outpatient Unit at the Clinic for Endocrinology and Metabolic Disorders, Faculty of Medicine, Skopje, R. Macedonia, were enrolled in the study. All patients gave their informed consent to participate in the study. Semen analysis was performed in accordance with the World Health Organization (WHO) guidelines. All patients were routinely screened for the presence of chromosomal aneuploidies of the $\mathrm{X}$ and $\mathrm{Y}$ chromosomes by quantitative fluorescent polymerase chain reaction (QF-PCR) analysis and for the presence of $\mathrm{Y}$ microdeletions by multiplex analysis of six sequence tagged sites (STS) in the three AZF regions. The studied group included 27 patients with a known cause of infertility ( $Y$ microdeletions, XXY, XX males and obstructive azoospermia representing $36 \mathrm{X}$ chromosomes). The other 195 patients were grouped according to the results of semen analysis (patients with azoospermia, $n=73$; severe oligozoospermia or sperm counts of $<5 \times 10^{6} / \mathrm{mL}, n=51$; mild oligozoospermia or sperm counts of $>5 \times 10^{6} / \mathrm{ml}, n=31$; and normozoospermia with unexplained couple infertility, $n=40$ ). In addition, 152 men who have fathered at least one child by natural conception and whose paternity was proved by DNA analysis served as controls.

Methods. Genomic DNA was isolated from leukocytes using the Proteinase K/SDS digestionphenol/chloroform extraction-ethanol precipitation method (9). The CAG repeat number was determined by fluorescent PCR amplification of exon 1 of the AR gene using the following primers: direct 5'-(HEX) TCC AGA ATC TGT TCC AGA GCG TGC-3' and reverse 5'-GCT GTG AAG GTT GCT GTT CCT CA-3'. The size of the PCR product was determined by capillary electrophoresis on an ABI PRISM ${ }^{\mathrm{TM}} 310$ Genetic Analyzer (Applied BioSystems, Foster City, CA, USA). The number of CAG repeats predicted by the Genescan software (Applied BioSystems) was compared with the actual CAG repeats determined by direct dideoxy terminator cycle sequencing using the Big Dye Terminator Sequencing Kit v1.0 (Applied BioSystems) in male DNA samples with 14, 19, 21, 25 and 29 CAG repeats. Figure 1 shows the Genescan profiles of DNAs with 19, 21, 23 and 26 CAG repeats, while Figure 2 shows part of the DNA sequence of AR gene exon 1 in a DNA sample with 19 CAG repeats.

Statistical Analysis. The frequencies of the CAG repeat alleles were compared between the various groups of infertile/subfertile males and fertile controls using the $\chi 2$ and Fisher's exact tests. Differences in the mean of (CAG)n length between different groups of patients vs. controls were tested by the independent samples t-test. Statistical significance was defined as $p<0.05$.

\section{RESULTS}

The distribution of CAG repeats in the subgroups of infertile/subfertile men and of fertile controls is shown in Figure 3. The range of CAG repeat number, mean CAG repeat length and median for all subgroups is given in Table 1. Mean CAG length did not differ between the subgroups of infertile/subfertile males and the fertile controls. The percentages of long CAG repeats (defined at the cut offs: $>26,>27$ and $>28$ ) are given in Table 2 . The highest number of long CAG repeats was found in patients with mild oligozoospermia, the difference being statistically significant when compared to fertile controls. 


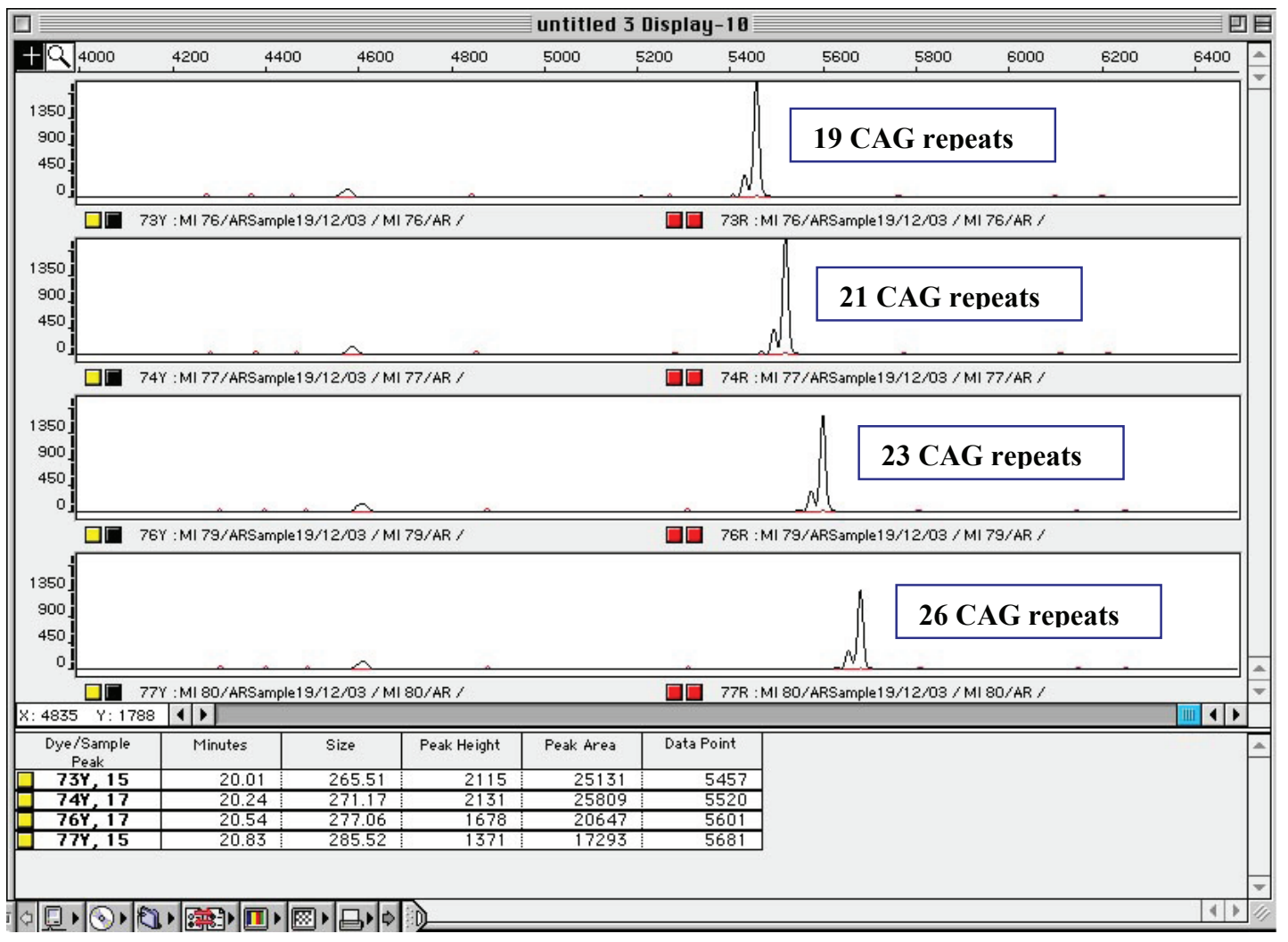

Figure 1. Genescan profiles of DNA samples with 19, 21, 23 and 26 CAG repeats in exon 1 of the AR gene.

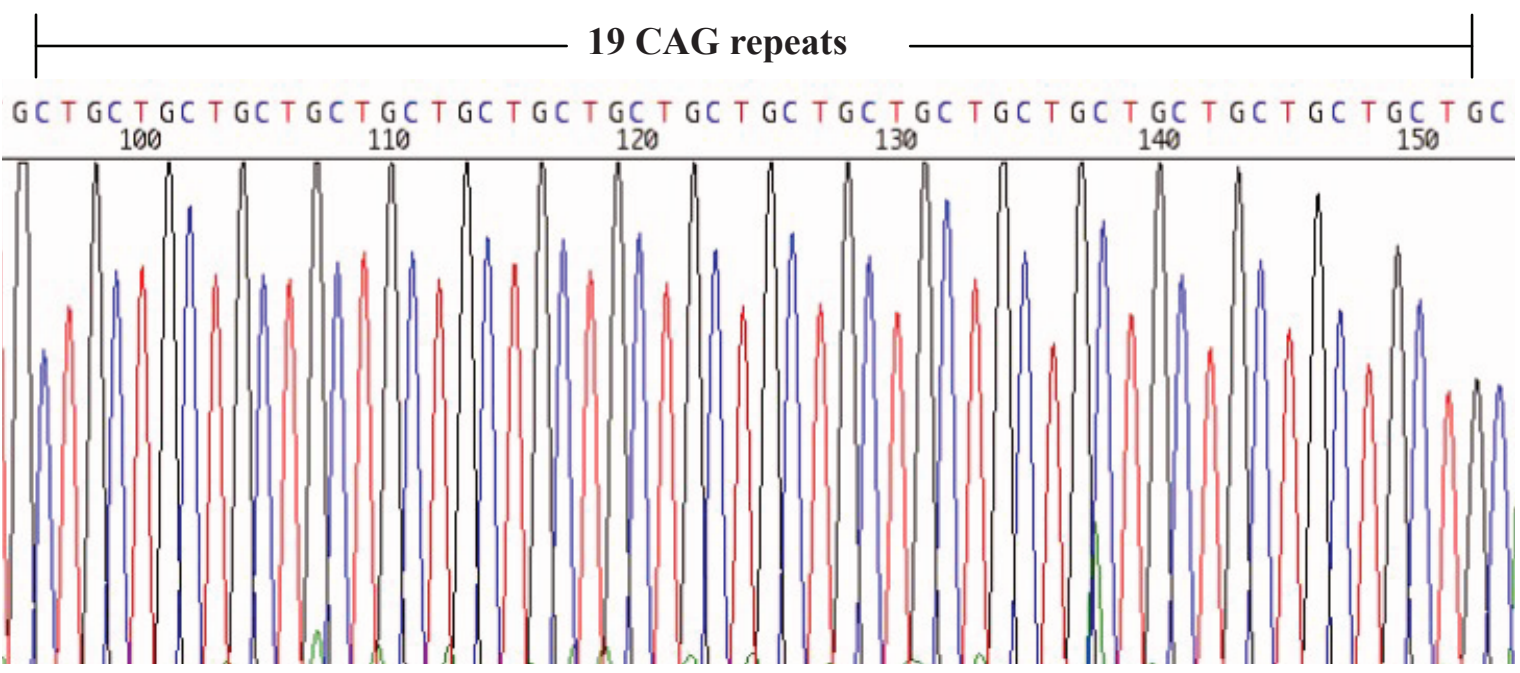

Figure 2. Part of a DNA sequence of exon 1 of the AR gene in a DNA sample with 19 CAG repeats.

\section{DISCUSSION}

Many studies have investigated the suggested link between increased CAG repeat length in exon 1 of the AR gene and depressed spermatogenesis and male infertility. Studies conducted in China [10], Singapore [11], Japan [12], Australia [13],
Greece [14] and France [15], have shown that longer CAG repeats are associated with defective spermatogenesis, while those conducted in Sweden [16], Finland [17], Germany [18], India [19], Italy [20] and Ireland [21], failed to find an association. The ethnic origin of the subjects and patient selection criteria have been suggested as contributing factors 


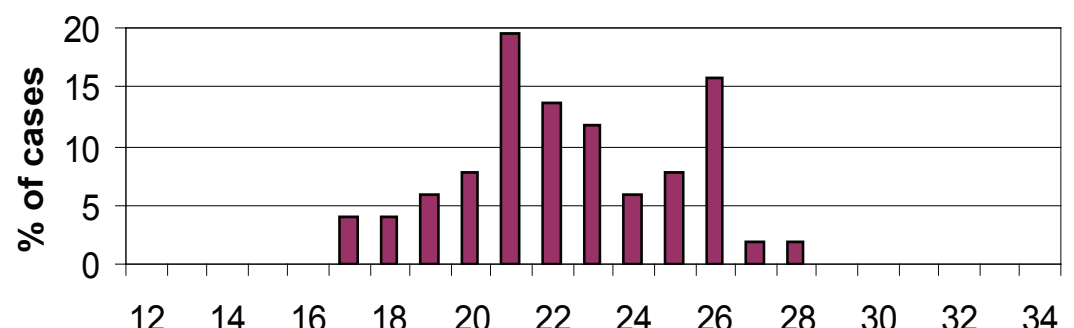

$\square$ oligozoospermia $<5$

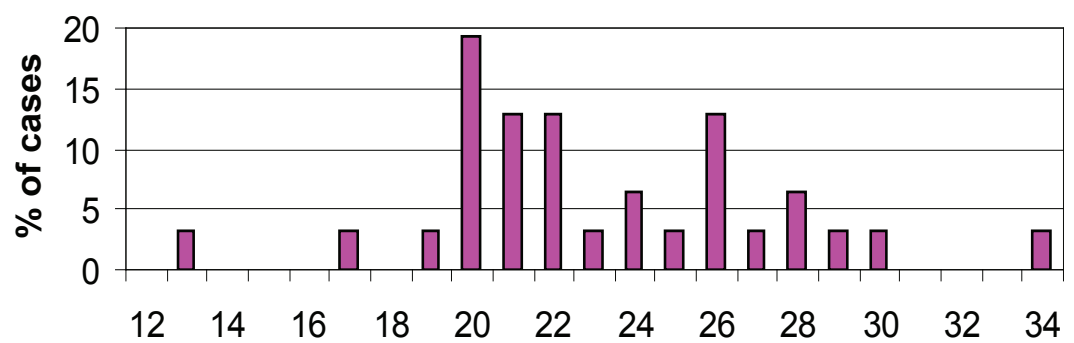

$\square$ oligozoospermia $>5$

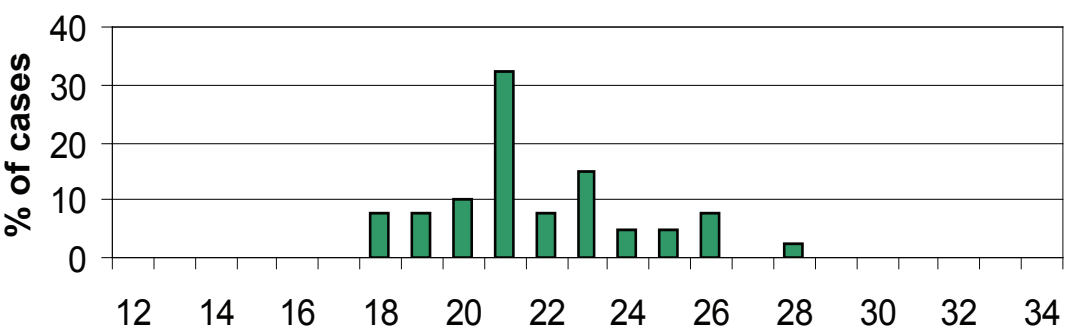

\section{$\square$ normozoospermia}

$\square$ fertile controls

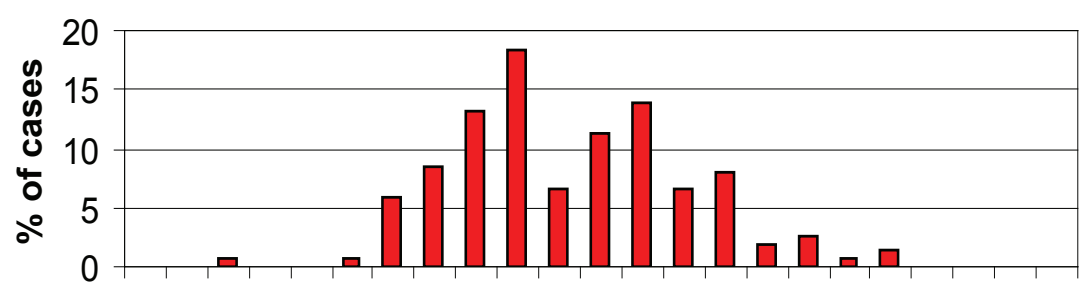

rertile controls

$\begin{array}{llllllllllll}12 & 14 & 16 & 18 & 20 & 22 & 24 & 26 & 28 & 30 & 32 & 34\end{array}$

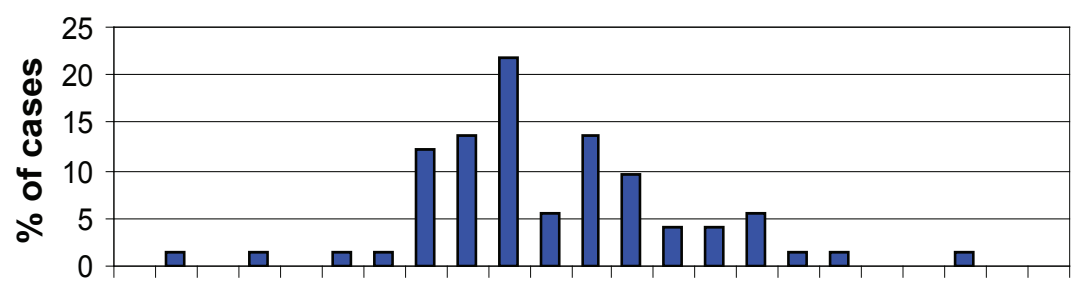

\section{$\square$ azoospermia}

$\begin{array}{llllllllllll}12 & 14 & 16 & 18 & 20 & 22 & 24 & 26 & 28 & 30 & 32 & 34\end{array}$

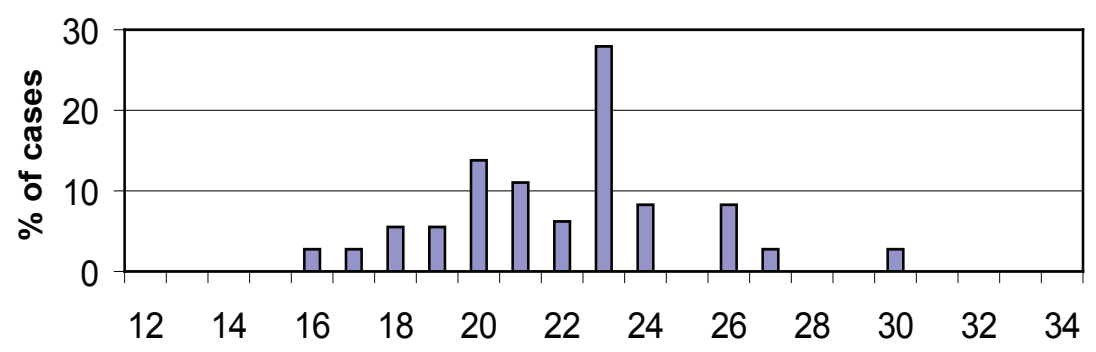

$\square$ known cause of infertility

Figure 3. Distribution of CAG repeats in exon 1 of the AR gene in infertile/subfertile males with different sperm counts (azoospermia, $n=73$; severe oligozoospermia, $n=51$; mild oligozoospermia, $n=31$; normozoospermia, $n=$ $40)$, infertile men with known cause of infertility $(n=36 \mathrm{X}$ chromosomes) and in fertile males $(n=152)$. 
Table 1. The CAG repeat numbers in different groups of infertile/subfertile patients and fertile controls

\begin{tabular}{|l|c|c|c|c|}
\hline Group & $\begin{array}{c}\text { Number of } \\
\text { Chromosomes }\end{array}$ & $\begin{array}{c}\text { CAG Repeat } \\
\text { Range }\end{array}$ & Mean \pm SD & Median \\
\hline Azoospermia & 73 & $13-32$ & $22.0 \pm 3.1$ & 21.0 \\
\hline Severe oligozoospermia & 51 & $17-28$ & $22.4 \pm 2.8$ & 22.0 \\
\hline Mild oligozoospermia & 31 & $13-34$ & $23.0 \pm 4.2$ & 22.0 \\
\hline Normozoospermia & 40 & $18-28$ & $21.8 \pm 2.4$ & 21.0 \\
\hline Known cause of infertility & 36 & $16-30$ & $22.0 \pm 2.9$ & 22.5 \\
\hline Fertile controls & 152 & $15-30$ & $22.3 \pm 3.9$ & 22.0 \\
\hline
\end{tabular}

Table 2. The percentage of long CAG repeats in different groups of infertile/subfertile patients and fertile controls

\begin{tabular}{|l|r|r|r|r|r|r|}
\hline Group & \multicolumn{3}{|c|}{ CAG Repeats } \\
\hline (number of chromosomes) & \multicolumn{2}{|c|}{$>\mathbf{2 8}$} & \multicolumn{2}{c|}{$>\mathbf{2 7}$} & \multicolumn{2}{c|}{$>\mathbf{2 6}$} \\
\hline & $\boldsymbol{n} \mathbf{( \% )}$ & \multicolumn{1}{|c|}{$\boldsymbol{p}$ Value } & $\boldsymbol{n} \mathbf{( \% )}$ & $\boldsymbol{p}$ Value & \multicolumn{1}{c|}{$\boldsymbol{n ( \% )}$} & $\boldsymbol{p}$ Value \\
\hline Azoospermia $(\mathrm{n}=73)$ & $2(2.7)$ & 0.449 & $3(4.1)$ & 0.866 & $7(9.6)$ & 0.424 \\
\hline Severe oligozoospermia $(n=51)$ & $0(0.0)$ & 0.410 & $1(2.0)$ & 0.401 & $2(3.9)$ & 0.486 \\
\hline Mild oligozoospermia $(n=31)$ & $3(9.7)$ & 0.009 & $5(16.1)$ & 0.018 & $6(19.4)$ & 0.022 \\
\hline Normozoospermia $(\mathrm{n}=40)$ & $0(0.0)$ & 0.266 & $1(2.5)$ & 0.553 & $1(2.5)$ & 0.323 \\
\hline Known cause of infertility $(n=36)$ & $1(2.8)$ & 0.529 & $1(2.8)$ & 0.625 & $2(5.6)$ & 0.821 \\
\hline Fertile controls $(n=152)$ & $2(1.3)$ & & $7(4.6)$ & & $10(6.6)$ & \\
\hline
\end{tabular}

for the conflicting reports [20]. To clarify the relevance of CAG repeat size and male infertility, further studies with more homogeneous infertile/ subfertile patients should be conducted.

We analyzed the number of CAG repeats among different subgroups of infertile/subfertile patients categorized according to their sperm counts (azoospermia, severe oligozoospermia, mild oligozoospermia and normozoospermia). All those with known causes of spermatogenic failure, such as $\mathrm{Y}$ microdeletions, $\mathrm{XXY}, \mathrm{XX}$ males and obstructive azoospermia were analyzed as a separate subgroup consisting of patients with a known cause of infertility.

This is the first report of the distribution of AR CAG repeats among men from R. Macedonia and the first to correlate the length of AR CAG repeat tracts with the impaired spermatogenesis and male infertility. We failed to find an association between the mean number of CAG repeats among any of the infertile/subfertile subgroups and the fertile controls. However, we found a significantly higher percentage of CAG repeats $>26(p=0.022),>27$ $(p=0.018)$ and $>28(p=0.009)$ in males with mild oligozoospermia. These results indicate a possible association between CAG repeat length and mild oligozoospermia. It is possible that long AR CAG repeat number acts as a low penetrance risk factor, which slightly impairs spermatogenesis, and probably acts in a more complex manner together with other genetic and/or environmental factors. Further studies on a larger number of patients with mild oligozoospermia are warranted to confirm the association between impaired spermatogenesis and mild oligozoospermia.

\section{ACKNOWLEDGMENTS}

This study was supported by grant No. 13-1000/305 from the Ministry of Education and Science, Skopje, R. Macedonia (to D. Plaseska-Karanfilska).

\section{REFERENCES}

1. De Kretser DM, Baker HWG. Infertility in men: recent advances and continuing controversies. J Clin Endocrinol Metab 1999; 84(10): 3443-3450.

2. LaSpada AR, Wilson EM, Lubahn DB, Harding AE, Fishbeck KH. Androgen receptor gene mutations in X-linked spinal and bulbar muscular atrophy. Nature 1991, 352(6330): 77-79.

3. Chamberlain NL, Driver ED, Miesfeld RL. The length and location of CAG trinucleotide repeats in the androgen receptor $\mathrm{N}$-terminal domain 
affect transactivation function. Nucleic Acids Res 1994; 22(15): 3181-3186.

4. Giovannucci E, Stampfer MJ, Krithivas K, Brown M, Dahl D, Brufsky A, Talcott J, Hennekens $\mathrm{CH}$, Kantoff PW. The CAG repeat within the androgen receptor gene and its relationship to prostate cancer. Proc Natl Acad Sci USA 1997; 94(7): 3320-3323.

5. Mifsud A, Ramirez S, Yong EL. Androgen receptor gene CAG trinucleotide repeats in anovulatory infertility and polycystic ovaries. J Clin Endocrinol Metab 2000;85: 3484-3488.

6. Lim HN, Chen H, McBride S, Dunning AM, Nixon RM, Hughes IA, Hawkins JR. Longer polyglutamine tracts in the androgen receptor are associated with moderate to severe undermasculinized genitalia in XY males. Hum Mol Genet 2000; 9(5): 829-834.

7. Haiman CA, Brown M, Hankinson SE, Spiegelman D, Colditz GA, Willett WC, Kantoff PW, Hunter DJ. The androgen receptor CAG repeat polymorphism and risk of breast cancer in the Nurses' Health Study. Cancer Res 2002; 62(4): 1045-1049.

8. Tut TG, Ghadessy FJ, Trifiro MA, Pinsky L, Yong EL. Long polyglutamine tracts in the androgen receptor are associated with reduced transactivation, impaired sperm production, and male infertility. J Clin Endocrinol Metab 1997; 82(11): 3777-3782.

9. Efremov GD, Dimovski AJ, PlaseskaKaranfilska D, Simjanovska L, Sukarova E, Koceva $\mathrm{S}$. Isolation of genomic DNA from mammalian cells. In: Efremov GD, Ed. A Laboratory Manual, 3rd ed. Skopje: Macedonian Academy of Sciences and Arts. 1999; 1-3.

10. Tse JY, Liu VW, Yeung WS, Lau EY, Ng EH, Ho PC. Molecular analysis of the androgen receptor gene in Hong Kong Chinese infertile men. J Assist Reprod Genet 2003; 20(6): 227-233.

11. Mifsud A, Sim CK, Boettger-Tong H, Moreira S, Lamb DJ, Lipshultz LI, Yong EL. Trinucleotide (CAG) repeat polymorphisms in the androgen receptor gene: molecular markers of risk for male infertility. Fertil Steril 2001; 75(2): 275-281.

12. Komori S, Kasumi H, Kanazawa R, Sakata K, Nakata Y, Kato H, Koyama K. CAG repeat length in the androgen receptor gene of infertile Japanese males with oligozoospermia. Mol Hum Reprod
1999; 5(1):14-16.

13. Dowsing AT, Yong EL, Clark M, McLachlan RI, de Kretser DM, Trounson AO. Linkage between male infertility and trinucleotide repeat expansion in the androgen-receptor gene. Lancet 1999; 354(9179): 640-643.

14. Kukuvitis A, Georgiou I, Bouba I, Tsirka A, Giannouli CH, Yapijakis C, Tarlatzis B, Bontis J, Lolis D, Sofikitis N, Papadimas J. Association of oestrogen receptor $\alpha$ polymorphisms and androgen receptor $\mathrm{CAG}$ trinucleotide repeats with male infertility: a study in 109 Greek infertile men. Int J Androl 2002; 25(3): 149-152.

15. Wallerand H, Remy-Martin A, Chabannes E, Bermont L, Adessi GL, Bittard H. Relationship between expansion of the CAG repeat in exon 1 of the androgen receptor gene and idiopathic male infertility. Fertil Steril 2001; 76(4): 769-774.

16. Giwercman YL, Xu C, Arver S, Pousette A, Reneland R. No association between the androgen receptor gene CAG repeat and impaired sperm production in Swedish men. Clin Genet 1998; 54(5): 435-436.

17. Lund A, Tapanainen JS, Lahdetie J, Savontaus ML, Aittomaki K. Long CAG repeats in the AR gene are not associated with infertility in Finnish males. Acta Obstet Gynecol Scand 2003; 82(2): 162-166.

18. Dadze S, Wieland C, Jakubiczka S, Funke K, Schroder E, Royer-Pokora B, Willers R, Wieacker PF. The size of the CAG repeat in exon 1 of the androgen receptor gene shows no significant relationship to impaired spermatogenesis in an infertile Caucasoid sample of German origin. Mol Hum Reprod 2000; 6(3): 207-214.

19. Thangaraj K, Joshi MB, Reddy AG, Gupta NJ, Chakravarty B, Singh L. CAG repeat expansion in the androgen receptor gene is not associated with male infertility in Indian populations. J Androl 2002; 23(6): 815-818.

20. Ferlin A, Bartoloni L, Rizzo G, Roverato A, Garolla A, Foresta C. Androgen receptor gene CAG and GGC repeat lenghts in idiopathic male infertility. Mol Hum Reprod 2004; 10(6): 417-421.

21. Lavery R, Houghton JA, Nolana A, Glennon $\mathrm{M}$, Egan D, Maher M. CAG repeat length in an infertile male population of Irish origin. Genetica 2005; 123(3): 295-302. 